\title{
Ultra-wide imaging in a case of retinal vasculitis with macular star
}

\author{
Abhishek Sheemar, Brijesh Takkar, Shreyas Temkar, Pradeep Venkatesh
}

Dr Rajendra Prasad Centre for Ophthalmic Sciences, All India Institute of Medical Sciences, New Delhi, India

\section{Correspondence to Dr Brijesh Takkar, britak.aiims@gmail.com}

Accepted 7 October 2017

\section{DESCRIPTION}

A 13-year-old Indian girl presented with painless vision loss in left eye since 3 months which was gradual in onset. She had been treated with intravenous steroids for optic neuritis 2 months earlier when her visual acuity had improved from 20/200 to 20/20 in left eye. Currently, she complained of recurrent episodic vision loss while taking low-dose oral steroids. On examination, visual acuity was 20/20 in right eye and 20/30 in left eye. Retrolental cells were present in both eyes (left greater than right) while intraocular pressures were normal. Fundus examination revealed active phlebitis with collateral vessels, vascular sclerosis and suspicious areas of new vessels in both eyes. Left eye additionally had a macular star (figure 1). She was clinically diagnosed to have bilateral retinal vasculitis with left eye macular star. Systemic examination was within normal limits.

On ultra-wide field fundus fluorescein angiography, both eyes had peripheral retinal neovascularisation with large capillary non-perfusion areas and collateral vessels (figure 2). Optical coherence tomography confirmed the findings of left macula. Mantoux was normal $(7 \times 7 \mathrm{~mm})$ as were chest X-ray, chest CT scan, complete blood count, serum

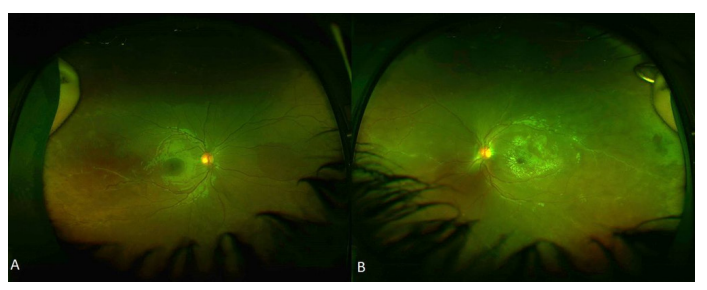

Figure 1 (A) Ultra-wide field image of right eye with active phlebitis in the inferior-temporal quadrant along with vascular sclerosis and veno-venous anastomosis. (B) Ultra-wide field image of left eye with macular star (hard exudates nasal to fovea), and temporal vascular sclerosis with active phlebitis.

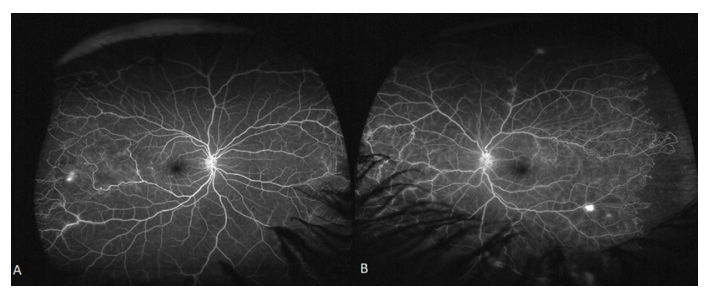

Figure 2 (A, B) Ultra-wide field fundus fluorescein angiography of right and left eyes with leakage from new vessels and peripheral capillary nonperfusion areas bordered by collateral vessels.
ACE levels and peripheral blood smear. Serum antinuclear antibody (ANA) and anti-neutrophil cytoplasmic antibodies (ANCA) were negative and the serum was non-reactive to HIV, venereal disease research laboratory (VDRL) and treponema pallidum haemagglutination assay (TPHA). Toxoplasmosis and Lyme disease were ruled out with serum ELISA test for the presence of antibodies. Further leading questions were asked for ruling out other causes of retinal vasculitis with macular star (see below).

This is an unusual case having retinal vasculitis with macular star (a partial one in this case) without a definitive cause. The findings of left eye initially may have been like a typical neuroretinitis with vasculitis prior to treatment with steroids for optic neuritis, though currently typical optic disc signs were absent. Such cases should be approached with possibility of infective and non-infective aetiologies, which may or may not be restricted to the eye.

The infectious causes of macular star in an inflamed eye include cat-scratch disease, syphilis, Lyme disease, toxoplasmosis, tuberculosis (TB), HIV infection and measles. The non-infectious causes include idiopathic retinal vasculitis aneurysm and neuroretinitis (IRVAN), polyarteritis nodosa, inflammatory bowel disease and Behçet's disease. ${ }^{1-3}$ Infectious causes were excluded appropriately as discussed above. IRVAN was excluded by the absence of aneurysmal dilatations on angiography. Eales vasculitis typically has peripheral retinal involvement in men and concurrent macular oedema is not commonly in the form of a macular star. Systemic history was not suggestive of other rare non-infective associations.

During the course of management over the next year, she received a 6-month course of anti-TB therapy and 3-week course of doxycycline apart from tapering courses of oral steroids in different local hospitals. Peripheral retinal ablation was also done in both eyes. Yet she had three episodes of

\section{Learning points}

- Presence of atypical signs in a case of retinal vasculitis, like macular star in this case, necessitates active surveillance for an underlying aetiology.

- It is possible that retinal vasculitis with macular star is an entity in itself or may even be a spectrum of other disease like idiopathic retinal vasculitis aneurysm and neuroretinitis or idiopathic retinal vasculitis. 
recurrent active phlebitis and even developed peripheral vitreous haemorrhage in left eye. She is on regular follow-up with us for future ocular or systemic manifestations.

Contributors AS, ST and PV diagnosed and managed the patient. AS and BT wrote the manuscript and PV critically revised it. ST did the imaging. PV holds the overall responsibility of the script.

Competing interests None declared.

Patient consent Parental/guardian consent obtained.

Provenance and peer review Not commissioned; externally peer reviewed. (c) BMJ Publishing Group Ltd (unless otherwise stated in the text of the article) 2017. All rights reserved. No commercial use is permitted unless otherwise expressly granted.

\section{REFERENCES}

1 Matsuda A, Chin S, Ohashi T. A case of neuroretinitis associated with long-standing polyarteritis nodosa. Ophthalmologica 1994;208:168-71.

2 Shoari M, Katz BJ. Recurrent neuroretinitis in an adolescent with ulcerative colitis. J Neuroophthalmol 2005;25:286-8.

3 Chan RV, Lee TC, Chaganti RK, et al. Macular star associated with Behçet disease. Retina 2006;26:468-70.

Copyright 2017 BMJ Publishing Group. All rights reserved. For permission to reuse any of this content visit http://group.bmj.com/group/rights-licensing/permissions.

BMJ Case Report Fellows may re-use this article for personal use and teaching without any further permission.

Become a Fellow of BMJ Case Reports today and you can:

- Submit as many cases as you like

- Enjoy fast sympathetic peer review and rapid publication of accepted articles

- Access all the published articles

Re-use any of the published material for personal use and teaching without further permission

For information on Institutional Fellowships contact consortiasales@bmjgroup.com

Visit casereports.bmj.com for more articles like this and to become a Fellow 